\title{
DAMPAK DIMENSI EKUITAS MEREK DALAM MEMBENTUK MINAT BELI ULANG
}

\author{
Vera Verdilla \\ Albari \\ Jurusan Manajemen, Fakultas Ekonomi, Universitas Islam Indonesia, Yogyakarta \\ Email: albari@uii.ac.id \\ Submitted: Jun 2, 2017; Reviewed: Jun 2, 2017; Accepted: Aug 1, 2017
}

\begin{abstract}
Along with the times, the economy grew by leaps and bounds. Many brands are popping up in the market. Brands competing to attract the attention of consumers. To cope with competition management must first understand the importance of the power contained within the dimensions of their brand equity. For that empirical research is intended to explain the relationship between the dimensions of brand equity, especially the positive influence of consumer repurchase intention. The population in this study are those who have never made a purchase in the clothing brand " $G$ " in Yogyakarta. The sample involved is as much as 166 respondents with a sampling technique in the form of convenience sampling. Variable data used for the analysis is brand awareness, brand image, perceived quality, brand loyalty, and purchase intention. Data were analyzed using multiple linear regression, which is equipped with six types of test data analysis. The results of data analysis showed that brand awareness and brand image positive and significant impact on the perceived quality of the brand. Furthermore, brand awareness, brand image and perceived quality and significant positive effect on brand loyalty. The study also found brand awareness, brand image, perceived quality, brand loyalty and a positive and significant impact on the repurchase intention. In other words, awareness and a positive brand image can affect directly or indirectly (through the perceived quality and brand loyalty) to the repurchase intention.
\end{abstract}

Keywords: Brand Awareness, Brand Image, Perceived Quality, Brand Loyalty, and Purchase Intention

\section{PENDAHULUAN}

Merek pada suatu kelompok produk industri telah menjadi fokus bahasan yang penting. Hal itu karena merek akan mempengaruhi sikap konsumen dan menciptakan asosiasi produk yang kuat (Sudomo, 2013). Pentingnya merek bagi konsumen pada dasarnya diukur dari dampak merek yang dipilih, misalnya tingkat loyalitas pembeli terhadap merek tersebut (Khan et al, 2015). Ketika sebuah merek mampu menarik perhatian dan minat pelanggan, maka terjadilah proses formulasi strategi inovasi dalam pengenalan merek (Chi et al, 2009). Apabila merek sudah dikenal oleh konsumennya, maka bukanlah hal yang sulit bagi merek untuk terus dikembangkannya ekuitas yang telah dimilikinya itu.

Merek yang sudah terbangun secara kuat dapat dikatakan memiliki ekuitas merek.
Perusahaan perlu melakukan upaya dalam meningkatkan ekuitas merek, karena ekuitas merek sangat penting untuk memperkuat reputasi perusahaan. Perusahaan yang mampu mengembangkan preferensi merek akan mampu melawan serangan dari para pesaing. Preferensi merek terbaik dapat memberikan jaminan kualitas bagi konsumennya (Khan et al, 2015).

Dimensi yang dapat digunakan untuk mengukur nilai ekuitas merek pelanggan, di antaranya melibatkan dimensi-dimensi kesadaran merek, citra merek, persepsi kualitas, loyalitas terhadap merek, dan aset-aset lain yang dimiliki oleh sebuah merek (Aaker, 1991). Khan et al (2015) menambahkan bahwa dengan meneliti empat dimensi ekuitas merek pertama tersebut melalui keterkaitan hubungan kausalitas, maka empat dimensi tersebut akan membangun ekuitas mereknya sendiri. 
Menurut Liwe (2013) kesadaran merek merupakan kemampuan penerimaan konsumen terhadap sebuah merek dalam benak mereka, yang ditunjukkan oleh kemampuan konsumen dalam mengingat kembali sebuah merek dan mengkaitkannya ke dalam kategori produk tertentu (Khan et al, 2015). Sedangkan citra merek adalah cerminan dari persepsi tentang merek di dalam memori seorang konsumen ketika mereka melihat merek tersebut dan kemudian menimbulkan minat beli (Kotler \& Keller, 2012).

Dimensi persepsi kualitas berupa penilaian tentang harga, bentuk, pilihan gaya, mutu produk, dan atribut yang lain. Konsumen kebanyakan menganggap persepsi kualitas sebagai konsep tertentu terhadap produk dan layanan fitur yang dimiliki suatu merek (Khan et al, 2015). Sementara loyalitas merek dapat juga digambarkan sebagai suatu ukuran keterlibatan pelanggan kepada sebuah merek (Durianto dkk, 2004). Khan et al (2015) menambahkan bahwa sejumlah penelitian ilmiah telah membuktikan bahwa di benak konsumen kualitas dan kesadaran merek merupakan prasyarat pembelian produk, sedangkan loyalitas merek berperan sebagai jaminan bahwa seorang konsumen akan membeli sebuah produk.

Keempat dimensi tersebut di atas selain dapat membangun ekuitas merek, juga dapat menentukan minat beli ulang terhadap merek tersebut (Kahn et al, 2015; Kotler \& Keller, 2012; Mao, 2010; Jones et al, 2002). Minat beli ulang dinilai sebagai aspek mendasar yang menentukan perilaku konsumen terhadap suatu merek. Minat beli ulang merupakan rancangan seseorang dalam waktu mendatang untuk benarbenar melakukan pembelian ulang secara aktual. Wee et al (2014) menekankan bahwa minat beli ulang memiliki implikasi dan pengaruh yang baik terhadap tindakan seorang konsumen (Wee et al., 2014). Beberapa penelitian menyatakan bahwa pembelian yang didasari oleh minat beli ulang yang tinggi biasanya memunculkan sikap konsumen yang tidak peduli apakah merek tersebut mahal ataupun murah dan tentunya hal tersebut sangat menguntungkan bagi merek yang dimaksud.

Secara umum minat beli ulang datang ketika konsumen awalnya hanya coba-coba untuk membeli beberapa produk (Wee et al, 2014), dan ketika mereka merasakan akan mendapatkan citra merek dan kualitas yang konsisten atau lebih baik, maka mereka akan melakukan pembelian ulang.
Namun pada kenyataannya masih sedikit penelitian yang menganggap bahwa ekuitas merek adalah sebagai kombinasi yang berpengaruh pada minat pembelian. Karena itu penelitian ini akan sangat penting dalam membangun ekuitas merek, agar ke depannya merek-merek yang ada dapat terus menunjukan eksistensi dan bersaing di pasar. Penelitian juga bisa memberikan kontribusi terhadap pengembangan perusahaan melalui pengelolaan ekuitas merek sebagai salah satu intangible asset, sehingga dapat dijadikan modal untuk menentukan keunggulan kompetitif perusahaan. Model penelitian yang dibangun pada penelitian ini juga sebagai alternatif tema penelitian selanjutnya, karena dimensi-dimensi ekuitas merek dipecah menjadi suatu rangkaian pengaruh yang tersusun berjenjang secara rasional dalam suatu bangunan teori, tidak lagi terbangun secara konvensional ketika dimensi ekuitas merek tersusun dengan tingkatan secara setara.

\section{KAJIAN PUSTAKA DAN HIPOTESIS:}

Bagian berisi bahasan tentang variabel-variabel penting yang digunakan dalam penelitian beserta keterkaitan antar variabelnya, sehingga dapat terjelaskan bangunan teori yang mendasari terbentuknya model struktural peneltian.

\section{Ekuitas Merek}

Ide utama dari ekuitas merek adalah bahwa kekuatan merek terletak dalam benak konsumen. Karena itu ekuitas merek didefinisikan sebagai seperangkat aset dan kewajiban yang terkait dengan merek, yang dapat menambah nilai atau bahkan dapat mengurangi nilai dari sebuah produk (Aaker, 1991). Khan et al (2015) meyakini bahwa ekuitas merek juga berkontribusi terhadap profitabilitas jangka panjang suatu perusahaan. Ekuitas merek juga diartikan sebagai nilai tambah yang diberikan pada produk maupun jasa (Kotler dan Keller, 2012). Sama halnya dengan menghitung nilai perusahaan, menghitung nilai pada ekuitas merek adalah mengurangi nilai kewajiban merek total dari nilai aset merek total (Brand Equity $=$ Brand Assets - Brand Liabilities) (Sumarwan, 2011).

Ekuitas merek dapat memberikan sejumlah keunggulan kompetitif bagi suatu perusahaan (Khan et al, 2015). Lebih lanjut Khan et al menjelaskan bahwa di antara sejumlah keunggulan tersebut adalah perusahaan dapat menikmati biaya pemasaran yang lebih kecil. Hal ini disebabkan: (1) telah tingginya kesadaran dan 
kesetiaan konsumen terhadap merek tersebut, (2) perusahaan memiliki posisi yang lebih kuat dalam melakukan negosiasi dengan distributor dan pengecer karena pelanggan mengharapkan mereka bisa menjual produk tersebut, (3) perusahaan dapat mengenakan harga yang lebih tinggi dari pada pesaingnya, dan (4) perusahaan lebih mudah dalam melakukan peluncuran perluasan merek karena merek tersebut sudah memiliki kredibilitas yang tinggi.

Ekuitas merek dapat dibangun melalui berbagai dimensi. Dimensi ekuitas tersebut di antaranya adalah dimensi kesadaran merek, citra merek, persepsi kualitas, dan loyalitas merek (Aaker, 1991). Pengertian masing-masing dimensi tersebut dapat dijelaskan di bawah ini.

\section{Kesadaran Merek}

Kesadaran merek adalah kemampuan seorang calon pembeli untuk mengenali dan mengingat kembali suatu merek sebagai bagian dari suatu kategori produk tertentu (Khan et al, 2015). Merek yang sudah dikenali maupun di sadari menghindarkan konsumen dari resiko perbedaan antara harapan dan kinerja pemakaian, karena adanya asumsi bahwa merek yang sudah dikenal dapat diandalkan (Jha, 2013). Karena itu, kesadaran merek dapat dijadikan sebagai key of brand asset atau kunci pembuka untuk masuk ke elemen penting yang lain. Berkait dengan nilai ekuitas merek, jika kesadaran merek itu sangat rendah maka hampir dipastikan bahwa ekuitas mereknya juga rendah (Durianto dkk, 2004).

Stahl et al (2012) berpendapat bahwa peran kesadaran merek dalam keseluruhan ekuitas merek tergantung dari besarnya tingkatan kesadaran yang dicapai oleh suatu merek. Merek dengan tingkat kesadaran merek yang lebih terkenal akan memiliki penilaian kualitas yang lebih baik (Khan et al, 2015), dan pangsa pasar yang lebih tinggi (Jha, 2013). Sementara itu Xu dan Chan (2010) menyatakan bahwa kesadaran merek mampu berpengaruh terhadap loyalitas merek. Di samping itu konsumen dengan kesadaran merek yang baik akan cenderung meningkatkan persepsi kualitas, loyalitas dan minat pembelian terhadap merek tersebut (Chi et al, 2009). Lebih lanjut lagi Khan et al (2015) mengemukakan bahwa kesadaran merek yang terbentuk di awal komunikasi pemasaran akan menciptakan persepsi kualitas, loyalitas jangka panjang dan minat beli ulang konsumen.

Berdasarkan pada penjelasan tersebut, maka dapat diformulasikan hipotesis sebagai berikut:
H1. Kesadaran merek memiliki pengaruh signifikan terhadap persepsi kualitas merek.

H2. Kesadaran merek memiliki pengaruh signifikan terhadap loyalitas merek.

H3. Kesadaran merek memiliki pengaruh signifikan terhadap minat beli.

\section{Citra Merek}

Citra merek adalah seperangkat keyakinan konsumen mengenai merek tertentu (Kotler \& Keller, 2012). Seiring dengan perkembangannya citra merek juga dapat didefinisikan sebagai persepsi terhadap merek yang direfleksi oleh asosiasi merek yang mengandung makna dalam memori konsumen (Khan et al, 2015). Khan et al mengakui bahwa sangatlah penting untuk membentuk citra positif pada sebuah merek, karena diharapkan dengan citra positif yang dimiliki maka di benak konsumen akan muncul sikap potif terhadap keberadaan merek tersebut. Diyakini bahwa citra merek yang terkenal akan dapat menimbulkan keunikan tersendiri di pasar (Aaker, 1991).

Uraian penjelasan dan pendapat tersebut menyiratkan bahwa mayoritas konsumen menggunakan citra merek sebagai persepsi kualitas dan nilai dari suatu merek (Ranjbarian et al, 2012). Ranjbarian et al (2012) juga menyatakan bahwa merek yang memiliki logo maupun gambar lebih berpotensi untuk mendapatkan konsumen yang loyal. Di samping itu konsumen menggunakan citra merek yang kuat untuk mengembangkan minat mereka untuk membeli merek tersebut (Khan et al, 2015; Kotler \& Keller, 2012).

Dengan penjelasan tersebut diajukan hipotesis sebagai berikut:

H4. Citra merek memiliki pengaruh signifikan terhadap persepsi kualitas.

H5. Citra merek memiliki pengaruh signifikan terhadap loyalitas merek.

H6. Citra merek memiliki pengaruh signifikan terhadap minat beli.

\section{Persepsi Kualitas}

Persepsi Kualitas adalah penilaian konsumen terhadap nilai tambah yang terdapat dalam sebuah produk (Khan et al, 2015). Konsumen biasanya mengevaluasi kualitas suatu merek berdasarkan perasaan dan pengalaman sebelumnya (Saleem et al, 2015). Konsumen kebanyakan menganggap persepsi kualitas sebagai konsep produk dan layanan fitur yang dimiliki suatu merek (Khan et al, 2015). Bentuk persepsi kualitas yang dimaksud dapat berupa 
harga, bentuk, pilihan gaya, mutu produk, dan atribut yang lain.

Lebih jauh Saleem et al (2015) mengatakan apabila telah muncul persepsi kualitas positif terhadap suatu merek, maka ada kemungkinan konsumen akan setia terhadap merek tersebut dan memunculkan loyalitas terhadap suatu merek. Pendapat tersebut menguatkan pendapat Jones et al (2002) dan Chi et al (2009) bahwa persepsi kualitas produk juga merupakan faktor paling penting yang memberikan kontribusi terhadap loyalitas merek dan minat beli. Sementara itu Ranjbarian et al (2012) berhasil membuktikan bahwa persepsi kualitas mampu berpengaruh positif terhadap minat pembelian ulang.

Sehubungan dengan bahasan di atas, maka dapat disusun hipotesis sebagai berikut:

H7. Persepsi kualitas memiliki pengaruh signifikan terhadap loyalitas merek.

H8. Persepsi kualitas memiliki pengaruh signifikan terhadap minat beli.

\section{Loyalitas Merek}

Loyalitas dapat didefinisikan berdasarkan perilaku pembeli (Griffin, 2005). Karena itu loyalitas merek merupakan sikap konsumen terhadap preferensi suatu merek ataupun produk (Mao, 2010), bahkan sebagai bentuk komitmen antara penyedia produk dengan konsumennya (Yuan et al, 2011). Sementara itu Kotler dan Keller (2012) menyatakan loyalitas merek dapat pula dipandang sebagai sebuah bentuk pilihan yang dilakukan konsumen untuk membeli merek tertentu dibandingkan merek yang lain dalam satu kategori produk. Bagi konsumen yang sudah loyal, mereka biasanya tidak lagi melakukan evaluasi merek. Justru mereka biasanya secara tidak sadar meyakinkan konsumen lain untuk mencoba merek tersebut (Oliver, 1999). Konsumen yang telah loyal akan bersedia membeli merek tersebut, bahkan akan rela membayar lebih (Mao, 2010).

Sementara itu lebih lengkap Khan et al (2015) mengungkapkan bahwa loyalitas merek berkaitan dengan nilai kepekaan konsumen yang tinggi terhadap suatu merek. Dengan adanya kepekaan ini, maka ketika muncul kebutuhan konsumen akan suatu produk, mereka akan berminat untuk melakukan pembelian produk dengan merek yang sudah mereka cintai (Khan et al., 2015). Karena itu konsep loyalitas pelanggan menjadi penting, terutama pada saat terjadi persaingan yang ketat dan pertumbuhan pasar yang rendah, agar perusahaan mampu bertahan 84 hidup (Aritonang, 2014). Sementara itu Chi et al (2009) berhasil membuktikan bahwa loyalitas merek berpengaruh positif terhadap minat beli.

$$
\text { Penjelasan tersebut dapat }
$$

diformulasikan dalam bentu hipotesis sebagai berikut:

H9. Loyalitas merek memiliki pengaruh signifikan terhadap minat beli

\section{Minat Beli Ulang}

Secara umum minat beli datang ketika konsumen awalnya hanya coba-coba untuk membeli beberapa produk (Wee et al, 2014). Tindakan tersebut sebagai bentuk reaksi emosional yang dihasilkan dari evaluasi keseluruhan konsumen terhadap produk (Wu \& Chen, 2014), serta melibatkan perasaan, pikiran, pengalaman, dan faktor eksternal sebelum mengambil keputusan pembelian (Yeh, 2015).

Sementara itu minat beli ulang muncul ketika konsumen memiliki preferensi pribadi ke arah merek atau produk tertentu pada waktu yang lalu, dan kemudian berkeinginan untuk mengulang preferensinya tersebut (Rizwan et al, 2014). Minat beli ulang dapat dijadikan tolak ukur kemungkinan konsumen untuk membeli produk dengan mempertimbangkan bahwa semakin tinggi minat beli ulang, maka semakin tinggi pula kesediaan konsumen untuk membeli suatu produk (Wee et al, 2014).

Minat beli ulang ini menciptakan suatu motivasi yang tetap terekam dalam benak konsumen dan menjadi suatu keinginan yang sangat kuat untuk mengaktualisasikan yang ada di dalam benaknya itu di masa depan (Yoestini \& Rahma, 2007). Karena itu minat beli ulang menjadi faktor penting untuk memprediksi perilaku konsumen (Rizwan et al, 2014).

Dari pemaparan kajian teoritik dan hipotesis di atas, maka dapat dikemukakan kerangka penelitian seperti pada Gambar 1.

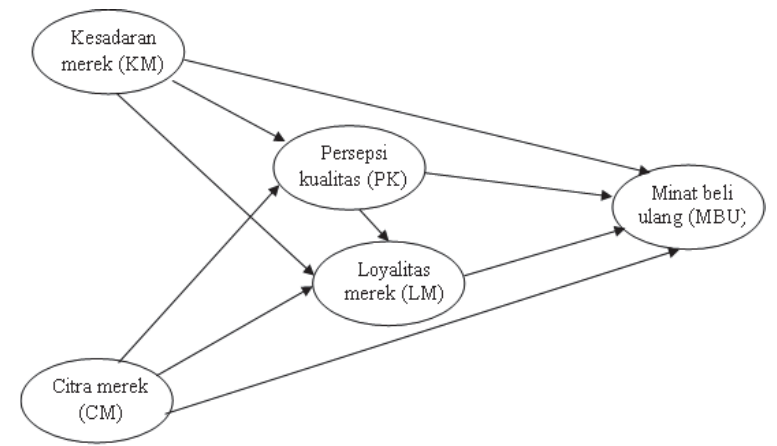

Gambar 1. Kerangka Penelitian (Khan et al, 2015) 
Gambar 1 tersebut menunjukan keterkaitan antara suatu variabel terhadap variabel yang lain. Kesadaran merek (KM) sebagai variabel antaseden berpengaruh positif terhadap persepsi kualitas (PK), loyalitas merek (LM), dan minat beli ulang (MBU). Hal yang sama juga terjadi pada variabel citra merek (CM). CM sebagai variabel antaseden kedua berpengaruh positif terhadap PK, LM, dan MBU. Sementara PK bisa berfungsi sebagai variabel antara dari pengaruh positif $\mathrm{KM}$ dan $\mathrm{CM}$ terhadap LM dan MBU. Sedangkan LM sendiri bisa sebagai variabel mediator dari pengaruh positif KM, CM, dan PK terhadap MBU. Keterkaitan antar variabel ini yang akan diuji secara empiris dalam penelitian ini.

\section{METODE PENELITIAN}

Subyek penelitian ini adalah seluruh mahasiswa di Yogyakarta yang sudah pernah membeli pakaian dengan merek "G". Elemen populasi yang dipilih sebagai subyek sampel adalah tidak terbatas, sehingga peneliti memiliki kebebasan untuk memilih sampel yang paling cepat dan murah. Karena itu jumlah sampel ditentukan sebanyak 166 responden. Jumlah tersebut diperoleh bedasarkan pada taraf signifikansi pengujian $(\alpha)$ sebesar $1 \%$ dan toleransi kesalahan dalam pengambilan sampel (E) $10 \%$. Untuk mendapatkan jumlah responden tersebut dilakukan dengan menggunakan metode convenience sampling. Proses operasionalnya adalah dengan meminta kesediaan pelanggan yang sedang memilih pakaian dengan merek "G" pada suatu outlet untuk menjadi responden penelitian.

Adapun definisi operasional variabel dari penelitian ini terangkum dalam Tabel 1.
Tabel 1. Definisi Operasional Variabel

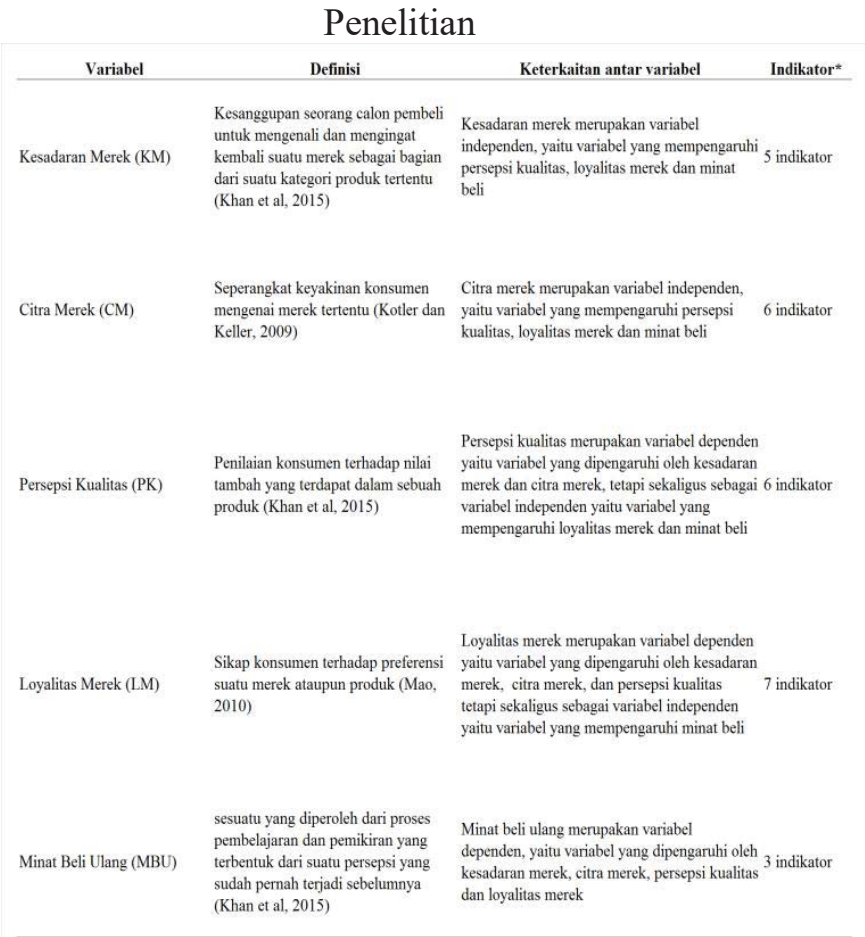

* Khan et al (2015), rincian indikator tercermin seperti pada Tabel 2

Sementara data analisis diperoleh dengan menggunakan instrumen angket. Angket penelitian berisi pernyataan-pernyataan dan tanggapan yang berkaitan dengan indikatorindikator seluruh variabel penelitian. Tanggapan setiap butir pernyataan pada masing-masing variabel tersebut disediakan secara tertutup dengan skala 5, mulai dari kategori sangat tidak setuju (skor 1) sampai dengan kategori sangat setuju (skor 5).

Sedangkan agar instrumen dan data penelitian mempunyai kualitas yang baik, maka dilakukan dua tahapan pengujian validitas dan reliabilitas. Uji kualitas instrumen dilakukan dengan melibatkan 30 responden, sedangkan untuk kualitas data dengan 166 responden. Uji validitas dilakukan dengan menggunakan pendekatan matrik korelasi, sedangkan uji reliabilitas memakai pendekatan nilai Cronbach Alpha. Indikator dinyatakan valid jika nilai korelasi antar indikator variabelnya positif dan lebih besar nilai korelasi kritis (tabel) pada taraf signifikansi 5\%, sedangkan variabel bisa disimpulkan reliabel jika nilai Cronbach Alpha $>0,60$ (Ghozali, 2012). Selengkapnya isi angket penelitian dan dua pengujian kualitas tersebut terangkum dalam Tabel 2.

Data yang lolos memenuhi uji kualitas digunakan untuk analisis data. Alat analisis data 
yang digunakan adaah dengan pendekatan tiga tahapan model regresi. Setiap tahapan analisis dilakukan melalui prosedur enam kriteria pengujian hipotesis, yaitu: uji-t, uji-F, uji normalitas data, uji heteroskedastisitas, uji multikolinearitas dan uji linearitas. Semua perhitungan dan analisis penelitian ini menggunakan bantuan program pengolah data SPSS versi 17.0.

\section{HASIL DAN PEMBAHASAN}

Tahapan pertama dari analisis penelitian ini adalah melakukan uji validitas dan reliabilitas instrumen (V/R INS.) dan data analisis (V/R Data). Nilai kritis validitas instrumen adalah $0.3061(\mathrm{n}=30)$, sedangkan validitas data sebesar 0.1281 ( $\mathrm{n}=166)$. Selanjutnya pernyataanpernyataan yang lolos uji kualitas digunakan untuk menghitung nilai rerata data. Selengkapnya indikator, hasil perhitungan validitas, reliabilitas, dan nilai rata-rata data dicantumkan dalam Tabel 2.

Dari hasil perhitungan validitas dan reliabilitas instrumen (V/R/INS) pada Tabel 2 dapat diketahui bahwa semua indikator pada semua variabel menunjukkan hasil korelasi product moment lebih besar dari nilai kritis 0.3061, serta nilai koefisien Cronbach Alpha lebih besar dari 0,6. Hal itu berarti semua indikator dan variabel tersebut dinyatakan valid dan reliabel, sehingga seluruhnya dapat digunakan kembali untuk mencari data analisis.

Tabel 2. Hasil Uji Validitas Reliabilitas Instrumen dan Data, Serta Rerata Data

\begin{tabular}{lcccc}
\hline Variabel/ Indikator & Kode & $\begin{array}{c}\text { V/R } \\
\text { KISS. }\end{array}$ & $\begin{array}{c}\text { V/R } \\
\text { DATA }\end{array}$ & $\begin{array}{c}\text { Rerata } \\
\text { Data }\end{array}$ \\
\hline Kecepatan mengenal karakteristik merek. & KM & $\mathbf{0 , 9 4 9}$ & $\mathbf{0 . 8 7 9}$ & $\mathbf{3 . 6 2}$ \\
Kemampuan mengenal merek di antara pesaing & KM1 & 0.672 & 0.641 & 3.65 \\
Mengenal promosi merek yang berbeda & KM2 & 0.69 & 0.607 & 3.58 \\
Merasa akrab denga merek & KM3 & 0.742 & 0.579 & 3.64 \\
Kemudahan mengenal logo merek. & KM4 & 0.681 & 0.553 & 3.51 \\
$\quad$ CITRA MEREK & KM5 & 0.622 & 0.566 & 3.69 \\
Keunggulan merek seperti yang diharapkan & CM & $\mathbf{0 , 8 5 6}$ & $\mathbf{0 . 9 0 5}$ & $\mathbf{3 . 6 3}$ \\
Merek menarik untuk dibeli & CM1 & 0.634 & 0.574 & 3.75 \\
Merek dapat mengekspresikan secara personal & CM2 & 0.712 & 0.564 & 3.5 \\
Merek mencerminkan kelas sosial yang tinggi & CM3 & 0.681 & 0.63 & 3.74 \\
Merek menimbulkan rasa bangga & CM4 & 0.468 & 0.544 & 3.49 \\
Merek membuat merasa nyaman & CM5 & 0.761 & 0.623 & 3.64 \\
$\quad$ PERSEPSI KUALITAS & CM6 & 0.624 & 0.598 & 3.64 \\
Merek yang berkualitas & PK & $\mathbf{0 , 8 5 8}$ & $\mathbf{0 . 9 3}$ & $\mathbf{3 . 7 6}$ \\
Bahan merek nyaman dipakai & PK1 & 0.449 & 0.473 & 3.79 \\
Merek memiliki variasi warna & PK2 & 0.494 & 0.548 & 3.72 \\
Merek awet dipakai & PK3 & 0.356 & 0.522 & 3.67 \\
Model merek bervariasi & PK4 & 0.714 & 0.626 & 3.74 \\
Setelan merek trendi & PK5 & 0.725 & 0.611 & 3.86 \\
$\quad$ LOYALITAS MEREK & PK6 & 0.454 & 0.456 & 3.78 \\
Merek menawarkan harga yang menarik. & LM & $\mathbf{0 , 8 4 2}$ & $\mathbf{0 . 7 2 3}$ & $\mathbf{3 . 7 7}$ \\
Kenaikan harga merek tidak mempengaruhi pembelian & LM1 & 0.433 & 0.455 & 3.8 \\
Merek menjadi pilihan utama & LM2 & 0.509 & 0.539 & 3.84 \\
Merek menimbulkan kepuasan & LM3 & 0.615 & 0.464 & 3.64 \\
Merek bisa direkomendasikan orang lain & LM4 & 0.659 & 0.511 & 3.67 \\
Tidak akan beralih merek & LM5 & 0.575 & 0.586 & 3.63 \\
Merek selalu dapat dipercaya & LM6 & 0.649 & 0.454 & 3.83 \\
$\quad$ MINAT BELI ULANG & LM7 & 0.701 & 0.573 & 3.96 \\
Merek akan dibeli dalam waktu dekat & MBU & $\mathbf{0 , 7 5 5}$ & $\mathbf{0 . 7 8}$ & $\mathbf{3 . 7 8}$ \\
Merek dipertimbangkan untuk dibeli di masa datang & MBU1 & 0.624 & 0.596 & 3.95 \\
Berminat membeli merek di masa datang & MBU2 & 0.71 & 0.456 & 3.73 \\
\hline & MBU3 & 0.542 & 0.531 & 3.67 \\
\hline & & & &
\end{tabular}

Sumber: Data primer diolah
Kesimpulan yang sama juga terjadi untuk pengujian validitas dan reliabilitas data analisis (V/R DATA). Hasil perhitungan validitas data pada Tabel 2 tersebut menunjukkan hasil korelasi yang indikator yang lebih tinggi dibandingkan dengan nilai kritis 0.1281 . Demikian pula nilai koefisien Cronbach Alpha dapat diperoleh lebih besar dari 0,6. Karena itu indikator dan variabel data analisis dapat dinyatakan valid dan reliabel, sehingga dapat digunakan untuk data analisis berikutnya. Penggunaan data yang lolos dalam pengujian kualitas data tersebut adalah untuk perhitungan rata-rata nilai indikator dan variabel penelitian.

Pada Tabel 2 menunjukkan bahwa seluruh indikator dan variabel menghasilkan penilaian dengan katagori tinggi (pada skala 1 sampai dengan 5). Dari sisi dimensi ekuitas merek, variabel loyalitas merek berhasil memperoleh penilaian tertinggi dibandingkan dengan persepsi kualitas, citra merek, dan yang terendah adalah variabel kesadaran merek. Sementara untuk indikator penelitian, penilaian responden yang tertinggi ditunjukkan pada indikator bahwa merek pakaian "G" selalu dapat dipercaya pada variabel loyalitas merek (LM7), dan diikuti dengan penilaian indikator model merek yang bervariasi pada variabel persepsi kualitas (PK5).

\section{Analisis Model Regresi}

Analisis Regresi Linier yang digunakan dalam penelitian ini adalah analisis regresi liner berganda. Terdapat tiga tahapan analisis (model) yang menggunakan pendekatan analisis regresi linier berganda ini. Model I digunakan untuk menetapkan adanya pengaruh positif kesadaran merek (KM) dan citra merek (CM) terhadap persepsi kualitas (PK). Model II berupa perhitungan untuk menetapkan adanya pengaruh positif $\mathrm{KM}$, CM, dan PK terhadap loyalitas merek (LM). Sedangkan Model III merupakan analisis regresi untuk menetapkan pengaruh positif $\mathrm{KM}, \mathrm{CM}$, dan $\mathrm{PK}$, LM terhadap minat beli ulang (MBU). Hasil perhitungan model-model regresi tersebut selengkapnya dapat dirangkum dalam Tabel 3. 
Tabel 3. Hasil Estimasi Regresi Linear Berganda

\begin{tabular}{ccccccccccc}
\hline VD & VI & Koef & Sig-t & Sig-F & Heter. & Normal & Linier & Multikol. & $\mathrm{r}^{2}$ & $\mathrm{R}^{2}$ \\
\hline PK & KM & 0.258 & 0.001 & & & & & 1.306 & 0.063 & \\
(I) & CM & 0.316 & 0 & 0,000 & 31.54 & 0.8 & 0.166 & 1.306 & 0.092 & 0,236 \\
\hline LM & KM & 0.149 & 0.048 & & & & & 1.394 & 0.024 & \\
(II) & CM & 0.186 & 0.015 & & & & & 1.438 & 0.036 & \\
& PK & 0.397 & 0 & 0,000 & 99.6 & 0.235 & 0.166 & 1.325 & 0.155 & 0,342 \\
\hline MBU & KM & 0.273 & 0 & & & & & 1.428 & 0.113 & \\
(III) & CM & 0.155 & 0.013 & & & & & 1.492 & 0.038 & \\
& PK & 0.137 & 0.031 & & & & & 1.569 & 0.028 & \\
& LM & 0.416 & 0 & 0,000 & 106.24 & 0.982 & 0.166 & 1.646 & 0.214 & 0.580 \\
\hline
\end{tabular}

Sumber: Data primer diolah

Hasil perhitungan di Tabel 3 menunjukkan bahwa pada model regresi I diperoleh koefisien variabel Sumber: Data primer diolah kesadaran merek (KM) dan citra merek (CM) adalah positif. Hasil tersebut dikuatkan dengan nilai perhitungan dengan pengujian $t$ dan $F$. Kedua pengujian menunjukkan nilai probabilitas signifikansi hitung mendekati 0,000 . Hal itu berarti hipotesis 1 dan 4 (H1 dan H4) yang menyatakan adanya pengaruh positif kesadaran merek (KM) dan citra merek (CM) terhadap persepsi kualitas (PK) secara signifikan. Hasil penelitian ini sekaligus menguatkan penelitian yang dilakukan oleh Khan et al (2015), Chi et al (2009), dan Ranjbarian et al (2012).

Di samping itu hasil uji klasik dari analisis data Model I menunjukkan hasil terpenuhinya asumsi klasik penggunaan model regresi I. Dalam perhitungan pengujian dan uji normalitas data (teknik Kolmogorof-Smirnov) menghasilkan nilai probabilitas lebih dari 5\%, sedangkan uji Multikolenieritas (teknik Variance Inflation Factor) menghasilkan nilai kurang dari 10. Demikian pula hasil pengujian heteroskedastisitas (teknik White) dan uji linieritas (teknik Lagrange Multiplier) dapat diperoleh nilai hitung c2 yang lebih kecil dari nilai c2 tabel (135.82). Dengan kata lain, model regresi-1 menunjukkan hasil pengujian hipotesis $\mathrm{H} 1$ dan $\mathrm{H} 4$ yang didukung secara empiris.

Sementara itu, jika dilihat dari koefisien determinan parsial (r2) hasil perhitungan menunjukkan bahwa nilai citra merek lebih dominan mempengaruhi persepsi kualitas dibandingkan dengan tingkat kesadaran merek. Meskipun nilai-nilai $\mathrm{r} 2$ tersebut masih rendah, namun koefisien variabel $\mathrm{KM}$ dan $\mathrm{CM}$ secara keseluruhannya dapat menghasilkan koefisien determinan ganda (R2) dengan total pengaruh yang cukup tinggi (0.236).

Dari Tabel 3 tersebut dapat dijelaskan juga hasil perhitungan model regresi-2. Perhitungan-perhitungan tersebut menunjukkan bahwa semua pengujian (3 uji) memenuhi kriteria dan asumsi pengujian yang memenuhi syarat sebagai model regresi yang baik.. Dengan demikian pada model regresi-2 dapat disimpulkan hipotesis-hipotesis yang menyatakan bahwa adanya pengaruh positif kesadaran merek (KM), citra merek (CM), dan persepsi kualitas (PK) terhadap loyalitas merek (LM) (H2, H5, dan H7) seluruhnya dinyatakan terbukti secara signifikan. Terbuktinya hipotesis-hipotesis penelitian secara empiris tersebut sejalan dengan hasil penelitian $\mathrm{Xu}$ dan Chan (2010), Jones et al (2002), Khan et al (2015), dan Saleem et al (2015).

Demikian pula pada model regresi-3 hipotesis-hipotesis tentang adanya pengaruh positif kesadaran merek (KM), citra merek (CM), persepsi kualitas (PK), dan loyalitas merek (LM) terhadap minat beli ulang (MBU) $(\mathrm{H} 3, \mathrm{H} 6, \mathrm{H} 8$, dan H9), dapat dinyatakan semuanya terbukti secara signifikan. Secara empiris hasil penelitian yang ditunjukan oleh model regresi-3 mampu menguatkan penelitian dari Chi et al (2009), Kotler dan Keller (2012), Ranjbarian et al (2012), dan Khan et al (2015).

Secara keseluruhan model-model regresi yang tercermin pada Tabel 2 tersebut di atas berhasil membuktikan secara empiris dari semua hipotesis-hipotesis yang telah diajukan pada bagian kajian pustaka dan hipotesis di depan. Hasil penelitian juga menunjukkan kesamaan hasil penelitian Khan et al (2015), dan secara parsial mendukung penelitian-penelitian lain seperti yang telah ditunjukkan di atas. Hasil penelitian sekaligus menguatkan pentingnya memecah dimensi-dimensi ekuitas merek secara berjenjang dengan dilandasi rasionalitas dalam suatu bangunan teori yang relevan.

Berkaitan dengan model regresi-2 yang menggunakan variabel loyalitas merek sebagai variabel dependen, hasil perhitungan koefisien determinan parsial (r2) menunjukkan variabel persepsi kualitas lebih dominan memberikan pengaruh terhadap perubahan loyalitas pembeli dibandingkan dengan variabel citra merek dan kesadaran merek. Sementara itu, pada model regresi-3 menunjukkan dominasi variabel yang bisa berpengaruh terhadap tingkat perubahan minat beli ulang tersebut adalah loyalitas merek, dan diikuti secara berturut-turut oleh variabel kesadaran merek, 
citra merek, dan persepsi kualitas. Tabel 3 juga menunjukkan bahwa pengaruh total (R2) variabel independen terhadap variabel dependen menjadi semakin besar dengan bertambah banyaknya jumlah variabel independen. Pernyataan ini ditunjukkan dengan besarnya R2 pada model regresi-1, 2 dan 3 .

Berdasarkan pada hasil perhitungan Tabel 3, juga dapat dihitung besarnya pengaruh prediktif total dari model regresinya. Hasil perhitungan didasarkan pada besarnya koefisien beta pada persamaan model regresi, yaitu sebagai berikut:

$\mathrm{PK}=0.258+0.316=0.574$

$\mathrm{LM}=(0.149+0.186+(0.574 \times 0.397)=0.563$

$\mathrm{MBU}=0.273+0.137+(0.563 \times 0.416)+0.155$

$=0.799$

Dari perhitungan di atas, maka besarnya pengaruh prediktif keseluruhan ekuitas merek terhadap minat beli ulang adalah sebesar 0.799. Hal itu berarti jika setiap dimensi ekuitas merek bertambah sebesar satu satuan, maka kemungkinan pembeli mengulang pembelian merek yang sama sebesar 0.799 satuan.

\section{Implikasi}

Hasil model regresi-1 menunjukkan pentingnya variabel citra merek untuk diperhatikan, karena terbukti merupakan variabel yang memiliki pengaruh yang lebih dominan terhadap persepsi kualitas merek "G" dibandingkan dengan variabel kesadaran merek. Untuk itu strategi yang diterapkan untuk meningkatkan persepsi kualitas produk merek "G" yaitu dengan: (1) meningkatkan performance (kinerja) yang sesuai harapan dan kebutuhan pelanggan, mempertahankan nama atau logo merek, agar tetap dikenal konsumen, dan (3) merek "G" dapat meyakinkan konsumen jika menggunakan produknya dapat meningkatkan rasa percaya diri, perasaan nyaman dan terhormat, yaitu dengan tetap mempertahankan citra produk "G" sebagai produk fashion yang terkenal dan branded.

Pentingnya meningkatkan variabel persepsi kualitas melalui citra merek tersebut di atas menjadi lebih penting dilakukan manajemen. Hal itu didukung dari hasil model regresi-2. Variabel persepsi kualitas merek terbukti merupakan variabel yang memiliki pengaruh dominan terhadap loyalitas merek "G" dibandingkan variabel kesadaran merek dan citra merek secara parsial. Karena itu perusahaan perlu untuk tetap mempertahankan variabel persepsi kualitas merek, yaitu dengan meningkatkan indikator yang dinilai paling rendah oleh konsumen (menggunakan merek "G" secara berkelanjutan). Di samping itu secara periodik perusahaan perlu mengeluarkan produk atau tren fashion baru yang sesuai dengan selera dan perkembangan mode, karena mayoritas pelanggan merek " $G$ " adalah anak muda atau eksekuif muda yang memiliki jiwa dinamis dan selalu up to date perkembangan fashion dunia.

Pentingnya perhatian pada jalur hubungan variabel citra merek--persepsi kualitas--loyalitas merek menjadi lebih penting, karena di antara empat variabel dari dimensi ekuitas merek yang berpengaruh terhadap minat beli ulang (model regresi-3), loyalitas merek terbukti merupakan variabel yang paling dominan berpengaruh. Karena itu sebaiknya perusahaan tetap mempertahankan variabel loyalitas merek, yaitu dengan meningkatkan indikator yang dinilai paling rendah oleh konsumen (akan merekomendasikan merek " $G$ " kepada orang lain). Konsumen akan merekomendasikan orang lain untuk membeli produk tertentu jika telah merasakan kepuasan pada produk tersebut, hal ini terjadi karena kualitas produk, pelayanan, dan performance produk sudah sesuai harapan. Oleh karena itu perusahaan sebaiknya terus melakukan inovasi-inovasi agar kinerja produk tetap baik dan terus mengalami peningkatan.

\section{KESIMPULAN DAN SARAN}

Perhitungan yang dilakukan atas data yang diperoleh dalam penelitian ini mempunyai konsistensi hasil analisis. Dari hasil analisis deskriptif diketahui dominasi hasil rerata dimensi ekuitas merek berturut-turut adalah variabel loyalitas, persepsi kualitas, citra merek, dan kesadaran merek. Urutan dominasi variabel tersebut lebih diperkuat oleh hasil perhitungan 3 model regresi yang dilakukan dalam penelitian ini. Model-model regresi tersebut menunjukkan hubungan variabel berupa jalur dominasi citra merek, persepsi kualitas, loyalitas, dan minat beli ulang. Karena itu penting untuk memprioritaskan perhatian terhadap urutan variabel-variabel tersebut agar minat beli ulang bisa menjadi optimal, utamanya jika sumber daya manajemen relatif terbatas untuk mengerjakan kegiatan yang dapat melingkupi semua variabel tersebut.

Hasil model regresi juga membuktikan adanya pengaruh yang semakin besar terhadap variabel dependen pada saat banyaknya variabel independen ditambahkan dalam model regresi. Dari sisi pengaruh prediktif total sebesar 0.799 
mengidentifikasikan bahwa empat dimensi ekuitas merek mampu berperan sangat signifikan dalam meningkatkan kemungkinan pelanggan dalam membeli ulang produk dan merek yang sama.

Meskipun penelitian ini berhasil membuktikan hipotesis-hipotesis yang diajukan, namun penelitian ke depan perlu dipertimbangkan untuk memperluas subyek dan atau sampel penelitian. Penelitian ke depan tidak hanya melibatkan pembeli pakaian, tetapi dapat diperluas pada merek-merek produk yang populer, seperti bisnis makanan atau restoran, peralatan listrik atau rumah tangga, dan kendaraan. Keragaman juga dapat dilakukan dengan menggunakan pendekatan analisis yang lain, misalnya dengan pendekatan structural equation model (SEM). Kedua perluasan penelitian tersebut dapat digunakan untuk memperoleh model penelitian ekuitas merek yang lebih mapan.

\section{REFERENSI}

Aaker, D.A. (1991). Managing Brand Equity: Capitalizing on the Value of a Brand Name. NewYork: The Free Press, Http://www.jstor.org/stable/3172832.

Diakses pada 31 Oktober 2015

Ajiwibawani, M.P. \& Edwar. M. (2015). Pengaruh Faktor Internal dan Ekternal Gaya Hidup Terhadap Keputusan Pembelian.(ejournal.unesa.ac.id/article/1 5634/54/article.pdf. Diakses 13 September 2016

Aritonang, L.R. (2014). Student Loyalty Modelling. Prethodno Priopcenje Preliminary Communication, 26 (1): 7791

Chi, H.K., Yeh, H.R., \& Yang, Y.Y. (2009). The Impact of Brand Awareness on Consumer Purchase Intention: The Mediating Effect of Perceived Quality and Brand Loyalty. The Journal of International Management Studies, 4 (1): 135-144

Durianto, D., Sugiarto, \& Sitinjak, T. (2004). Strategi Menaklukkan Pasar Melalui Riset Ekuitas dan Perilaku Merek, Jakarta: Gramedia Pustaka Utama

Ghozali I. (2012). Aplikasi Analisis Multivariate dengan Program SPSS, Semarang: BP Undip

Griffin, J. (2005). Consumer Loyality. Jakarta: Erlangga
Jha, M. (2013). Brand Awareness and Consumer Preference with Reference to FMEG Sector in Rural Bihar. International Journal of Advanced Research in Management and Social Sciences, 2(11), $75-85$

Jones, M. A., Mothersbaugh, D. L., \& Beatty, S. E. 2002. Why Customers Stay: Measuring The Underlying Dimensions Of Services Switching Costs And Managing Their Differential Strategic Outcomes. Journal of Business Research, 55 (6), 441-450

Khan, N., Rahmani, S.H.R., Hoe, H.Y., \& Chen, T.B. (2015). Causal Relationships among Dimensions of Consumer-Based Brand Equity and Purchase Intention: Fashion Industry. Canadian Center of Science and Education, 10(1), 172-181

Kotler, P. \& Keller, K.L. (2012), Marketing Management, $14^{\text {th }}$ ed., New Jersey: Pearson Prentice Hall

Kotler. (1974). Atmospheric as A Marketing Tool. Journal of Retailing. 49(4) Winter 1973-1974.

Liwe, F. (2013). Kesadaran Merek, Keragaman Produk, dan Kualitas Produk Pengaruhnya terhadap Pengambilan Keputusan Konsumen Membeli Di Kentucky Fried Chicken Manado". Jurnal EMBA, 1(4), 2107-2116

Mao, J. (2010). Customer Brand Loyalty. International Journal of Business and Management, 5(7), 213-217

Oliver, R.L. (1999). Whence Consumer Loyalty. Journal of Marketing, 63, 33-44

Ranjbarian, B., Sanayei, A., Kaboli, N.R., \& Hadadian, A. (2012). An Analysis of Brand Image, Perceived Quality, Customer Satisfaction and Re-purchase Intention in Iranian Department Stores. International Journal of Business and Management, 7(6), 40-48

Rizwan, M., Qoyyum, M., Qadeer, W., \& Javed, M. (2014). The Impact On Branded Product On Consumer Purchase Intentions. Journal of Public Administration and Governance, 4(3), 57-74

Saleem, A., Ghafar, A., Ibrahim, M., Yousuf, M., \& Ahmed, N. (2015). Product Perceived Quality and Purchase Intention with Consumer Satisfaction. Global Journal of Management and Business Research: E-Marketing, 15(1), 20-28 
Stahl, F., Heitmann, M., Lehmann, R.D., \& Neslin, A.S. (2012). The Impact of Brand Equity on Customer Acquisition, Retention, and Profit Margin. Journal of Marketing, 76, 44-63

Sudomo, S.T. (2013). Pengaruh Ekuitas Merek Terhadap Keputusan Pembelian (Studi Kasus Konsumen Pepsodent Di Kabupaten Bantul). JBMA, 1(2), 33-48

Sumarwan, U. (2011). Perilaku Konsumen: Teori dan Penerapannya dalam Pemasaran. Edisi 2 Cetakan 1, Jakarta: PT Ghalia Indonesia

Wee, C.S., Ariff, M.S.B.M., Zakuan, M., \& Tajudin, M.N.M. (2014). Consumers Perception, Purchase Intention and Actual Purchase Behavior of Organic Food Products. Review of Integrative Business and Economic Research, 3(2), 378-397

Wu, S.I. \& Chen, Y.J. (2014). The Impact of Green Marketing and Perceived Innovation on Purchase Intention for Green Products. International Journal of Marketing Studies, 6(5), 1-20

Yeh, H. (2015). Effects of Ict's Innovative Applications on Brand Image and Customer's Purchase Intention. The International Journal of Organizational Innovation, 7(4), 31-47

Yoestini \& Rahma., E.S. (2007). Analisis Pengaruh Kualitas Pelayanan Dan Citra Merek Terhadap Minat Beli Dan Dampaknya Pada Keputusan Pembelian (Studi Pada Pengguna Telepon Seluler Merek Sony Ericson Di Kota Semarang). Jurnal Sains Pemasaran Indonesia, 4(3), 261-276

Yuan, X., Song, T.H., \& Kim, S.Y. (2011). Cultural Influences on Consumer Value, Needs and Consumer Loyalty Behavior: East Asian Culture Versus Eastern European Culture. African Journal of Busniness Management, 5(30), 1218412196

Xu, J.B. \& Chan, A. (2010). A Conceptual Framework of Hotel Experience and Customer-based Brand Equity. International Journal of Contemporary Hospitality Management, 22(2), 174-193 